PSICOLOGIA, SAÚDE \& DOENÇAS, 2021, 22(2), 411-422

ISSN - 2182-8407

Sociedade Portuguesa de Psicologia da Saúde - SPPS - www.sp-ps.pt

DOI: http://dx.doi.org/10.15309/21psd220208

\title{
SEXUAL FUNCTION, PERSONALITY, AND BODY AWARENESS
}

\author{
Pedro Campos ${ }^{1}$, Marc Wittmann ${ }^{2}, \&$ Rui Costa ${ }^{3}$ \\ ${ }^{1}$ ISPA - Instituto Universitário, Lisbon, Portugal, pedrotomazcampos@gmail.com \\ ${ }^{2}$ Institute for Frontier Areas of Psychology and Mental Health, Freiburg, Germany, wittmann@igpp.de \\ ${ }^{3}$ William James Center for Research, ISPA - Instituto Universitário, Lisbon, Portugal, rcosta@ispa.pt
}

\begin{abstract}
Associations between Big Five personality traits and sexual function have been reported by many studies. Additionally, temporary alterations of consciousness influence sexual functioning. The present study examined how sexual responsiveness is independently associated with Big Five Personality traits and intensity of awareness of body, time, and surrounding space. One hundred thirty six heterosexual Portuguese women answered an online survey. Big Five personality traits were measured by the NEO-FFI-20. To assess responsiveness during the last sexual intercourse, participants completed measures on sexual satisfaction, desire, arousal, and orgasm occurrence, as well as awareness of body, space and time. Satisfaction and orgasm were associated to higher extraversion, higher conscientiousness, and lower neuroticism. Desire and arousal correlated with higher extraversion and lower neuroticism. Greater body awareness and lesser time awareness correlated with satisfaction, desire, and arousal. Body awareness was inversely related to time awareness. Satisfaction was independently predicted by body awareness, being in a relationship, extraversion, openness to experience, and conscientiousness. Desire was independently predicted by body awareness and lower neuroticism. Arousal was independently predicted by body awareness, openness to experience, and lower neuroticism. The findings provide knowledge on how sexual responsiveness might be independently influenced by stable personality factors and transient changes of consciousness.
\end{abstract}

Keywords: sexual function, personality, body awareness, time awareness, alterations of consciousness.

\section{FUNÇÃO SEXUAL, PERSONALIDADE E CONSCIÊNCIA CORPORAL}

RESUMO: Diversos estudos têm relatado associações entre os traços de personalidade Big Five e a função sexual. Além disso, o funcionamento sexual é influenciado por modificações temporárias de consciência. O presente estudo examinou de que forma a resposta sexual está independentemente associada aos traços de personalidade Big Five e à intensidade da consciência do corpo, do tempo e do espaço circundante. Cento e trinta e seis mulheres portuguesas heterossexuais responderam a um questionário online. Os traços Big Five foram mensurados através do NEO-FFI-20. Para avaliar a responsividade durante a última relação sexual, as participantes responderam a medidas de satisfação sexual, desejo, excitação, ocorrência de orgasmo, consciência corporal, consciência do

Rua do Jardim do Tabaco 34, 1149-041, Lisbon, Portugal. Email: rcosta@ispa.pt 


\section{SEXUAL FUNCTION, PERSONALITY, AND BODY AWARENESS}

espaço e consciência do tempo. A satisfação e o orgasmo associaram-se a maior extroversão, maior conscienciosidade e menor neuroticismo. O desejo e excitação correlacionaram-se com maior extroversão e menor neuroticismo. Maior consciência corporal e menor consciência do tempo associaram-se com satisfação, desejo e excitação. A percepção corporal associou-se inversamente à percepção do tempo. Maior consciência corporal, estar num relacionamento, maior extroversão, maior abertura à experiência e maior conscienciosidade foram preditores independentes da satisfação. Maior consciência corporal e menor neuroticismo foram preditores independentes do desejo. Menor neuroticismo, maior consciência corporal e maior abertura à experiência foram preditores independentes da excitação. Os resultados mostram como a responsividade sexual poderá ser influenciada de forma independente por factores de personalidade estáveis e mudanças transitórias de consciência.

Palavras-Chave: função sexual, personalidade, consciência corporal, consciência do tempo, alterações de consciência.

Recebido em 08 de fevereiro de 2021/ Aceite em 23 de maio de 2021

Sexual functioning is influenced by many sorts of factors. It can be influenced by contextual, ephemeral, physiological changes and mental states, as well as by more stable factors, such as personality traits, which refer to individual differences in "relatively enduring styles of thinking, feeling, and acting (McCrae \& Costa, 1997, p. 509). There is controversy regarding what are the core personality traits and several models have been proposed. According to the widely accepted Five Factor Model, personality has five basic universal dimensions: Neuroticism (N), Extraversion (E), Openness to Experience (O), Agreeableness (A), and Conscientiousness (C) (Costa \& McCrae, 1992; McCrae \& Costa, 1997)

This Five Factor Model of personality reflects on individual differences in sexual function, as consistent patterns of relationships between the Big Five traits and dimensions of sexual functioning have been reported by many studies. For both sexes, better sexual function has been related to higher $\mathrm{E}$, higher $\mathrm{C}$, and lower N. Inconsistent relationships have been found for $\mathrm{O}$ and $\mathrm{A}$. People higher in E tend to report higher sexual desire and are less likely to report symptoms of sexual dysfunctions. Those higher in $\mathrm{C}$ tend to report more sexual satisfaction and less symptoms of sexual dysfunction. In contrast, those higher in $\mathrm{N}$ report more sexual dissatisfaction and more symptoms of sexual dysfunction (Allen \& Walter, 2018a; Costa et al., 1992; Cardoso \& Costa, 2020; Eysenck, 1971; Jirjahn \& Ottenbacher, 2020; Kurpisz et al., 2017; Meltzer \& McNulty, 2016; Quinta Gomes \& Nobre, 2011; Velten et al., 2018).

As opposed to stable personality traits, more contextual and transient variables can influence sexual functioning, such as temporary alterations of consciousness. Examples of changes in consciousness in daily life may help to illustrate changes in consciousness during sexual activity. When we are attentively absorbed in a pleasurable task, there is substantial loss of awareness of time, and to some extent of loss of awareness of body and surrounding space (Wittmann, 2015, 2018). This is typical of flow states. In contrast, when we lay down to sleep or relax, the attention gets inward, and the awareness of body is intensified, as the awareness of surrounding space fades away. Sex combines intensified inward and outward attention; the attention is directed inwardly in the sense that bodily awareness is enhanced, sometimes concomitantly with sexual fantasies. The attention is also directed outwardly as one becomes attentionally absorbed by the partner and loses track of time in a way analogous to flow states. It is expected that the depth of these alterations of consciousness correlates with greater sexual responsiveness. Costa et al. (2016) queried women and men regarding their perception of body, time and space during the last sexual relation. Participants were also instructed to rate the satisfaction, desire, and arousal, and if orgasm occurred, during the last sexual relation. It was found that, for women, satisfaction, desire, arousal and orgasm correlated with greater 
body awareness and loss of time awareness. Higher desire correlated with lower awareness of surrounding space. For men, satisfaction, desire, arousal, and orgasm were also associated with greater body awareness. Higher desire and arousal were related to loss of awareness of surrounding space; satisfaction was related to loss of time awareness.

However, it is presently unclear if the degree of alteration of consciousness during sexual activity correlates with sexual responsiveness, independently of the influence of personality traits. Based on the previous research, the present investigation tested the hypotheses that higher sexual responsiveness during the last sexual intercourse is associated with extraversion, conscientiousness, lower neuroticism, greater body awareness, loss of time awareness, and loss of space awareness. Additionally, we ran regression models to explore how sexual responsiveness is independently predicted by alterations of consciousness and personality traits.

\section{METHOD}

\section{Participants}

One hundred thirty-six heterosexual Portuguese women participated by completing an online survey. The questionnaire was developed on Google Forms online platform. The average age was 29.97 years $(S D=11.64$; range: $18-63)$. Descriptive statistics are presented in Table 1 . The sample size was obtained after excluding 15 participants who reported to have consumed alcohol and/or cannabis during the last sexual intercourse. Those who were under the effect of alcohol and/or cannabis during the last intercourse were less aware of time (Welch's test $=3.86 ; d f=33.48, p<$ .001 ), marginally less aware of surrounding space (Welch's test $=2.01 ; d f=19.05 ; p=.059$ ), and lower in C (Welch's test $=2.59, d f=19.18 ; p=.032$ ). Consuming alcohol and/or cannabis did not affect body awareness and sexual responses, and was unrelated to other personality traits (all $p>$ .180). We included six women who smoked tobacco, as smoking tobacco is not clearly related to alterations of consciousness, and the great majority of studies do not find associations between tobacco smoking and female sexual function (Allen \& Walter, 2018b; Cardoso \& Costa, 2020). In the present study, smoking tobacco was unrelated to sexual responses and alterations of consciousness (all $p>.160)$. 
Table 1. Descriptive statistics $(N=136)$.

\begin{tabular}{|c|c|}
\hline & $N(\%)$ or Mean $(\mathrm{SD})$ \\
\hline Age & $29.97(11.64)$ \\
\hline \multicolumn{2}{|l|}{ Marital status } \\
\hline Single & $99(72.8 \%)$ \\
\hline Married & $24(17.6 \%)$ \\
\hline Divorced & $11(8.1 \%)$ \\
\hline Widowed & $1(.7 \%)$ \\
\hline \multicolumn{2}{|l|}{ Educational qualifications } \\
\hline Middle school & $1(.7 \%)$ \\
\hline High school & $40(29.4 \%)$ \\
\hline University attendance & $6(4.4 \%)$ \\
\hline Undergraduate & $53(39 \%)$ \\
\hline Master's & $35(23.5 \%)$ \\
\hline Ph.D. & $2(1.5 \%)$ \\
\hline \multicolumn{2}{|l|}{ Relationship characteristics } \\
\hline Ongoing relationship & $110(80.9 \%)$ \\
\hline Cohabiting & $50(36.8 \%)$ \\
\hline Relationship duration (months) & $83.83(91.345)$ \\
\hline
\end{tabular}

Table 2. Descriptive statistics of sexual responses.

\begin{tabular}{|c|c|}
\hline & $N(\%)$ or Mean $(S D)$ \\
\hline Body awareness [1 ... 7] & $6.07(1.43)$ \\
\hline Space awareness $[1 \ldots 7]$ & $3.57(1.54)$ \\
\hline Time awareness $\left[\begin{array}{lll}1 & \ldots & 7\end{array}\right]$ & $2.87(2.99)$ \\
\hline Satisfaction $[1 \ldots 7]$ & $5.82(1.38)$ \\
\hline Desire $[1 \ldots 7]$ & $6.07(1.33)$ \\
\hline Arousal $[1 \ldots 7]$ & $6.02(1.30)$ \\
\hline Orgasm $^{1}$ & $120(88.2 \%)$ \\
\hline Coital orgasm without clitoral masturbation ${ }^{1}$ & $52(38.2 \%)$ \\
\hline Coital orgasm with clitoral masturbation ${ }^{1}$ & $73(53.7 \%)$ \\
\hline Noncoital orgasm ${ }^{1}$ & $67(50.0 \%)$ \\
\hline
\end{tabular}
Nota: ${ }^{1}$ Orgasm did occur

\section{Measures}

Big Five personality traits were measured by the NEO-FFI-20 (Bertoquini \& Pais-Ribeiro, 2006), a Portuguese short version of the NEO-PI-R (Costa \& McCrae, 1995). It is composed by 20 items, five items for each of the five traits: neuroticism $(N)$, extraversion $(E)$, openness to experience $(O)$, agreeableness (A), and conscientiousness (C).

Sexual satisfaction, desire, and arousal, during last intercourse were assessed on a scale from 1 (absolutely nothing) to 7 (extremely). Additionally, participants reported if they had an orgasm during (1) penile-vaginal intercourse without clitoral masturbation, 2) penile-vaginal intercourse with clitoral masturbation, 3 ) noncoital sex (scores: $0=$ orgasm did not occur, $1=$ orgasm did occur). It was also used a composite measure for assessing orgasm occurrence regardless of the sexual behaviour that triggered it (scores: $0=$ no orgasm during last sexual activity, $1=$ orgasm did occur during last sexual activity) (Costa et al., 2016)

Body awareness and space awareness during intercourse were assessed by asking participants to describe how intensely they felt themselves and space. Answers were given on visual analogue scales 
consisting of seven drawings of a human figure and a room, respectively. The seven drawing had lines of increasing thickness with greater thickness indicating greater awareness, and were rated from 1 (absolutely nothing) to 7 (extremely) (Costa et al., 2016). Time awareness during the last intercourse was assessed by asking participants how intensely they perceived time. Answers were given on a scale from 0 (not at all) to 10 (extremely intensely).

\section{RESULTS}

As displayed in the Table 3, sexual satisfaction and orgasm correlated with higher E, higher $\mathrm{C}$, and lower N. Desire and arousal correlated with higher E and lower N.

Table 3. Pearson's correlations between sexual function and personality.

\begin{tabular}{ccccc}
\hline & \multicolumn{4}{c}{ Sexual Functioning } \\
\hline & Sexual Satisfaction & Arousal & Orgasm & Desire \\
& $r(p)$ & $r(p)$ & $r(p)$ & $r(p)$ \\
\hline Neuroticism & $-.20^{* *}$ & $-.26^{* *}$ & $-.18^{*}$ & $-.23^{* *}$ \\
Extroversion & $.30^{* * *}$ & $.20^{*}$ & $.24^{* *}$ & $.18^{*}$ \\
Openness & .07 & .10 & .07 & .05 \\
Agreeableness & .07 & .03 & .06 & .06 \\
Conscientiousness & $.30^{* * *}$ & .12 & $.18^{*}$ & .13 \\
\hline
\end{tabular}

Nota: *** $p \leq .001 ; * * p \leq .01 ; * p<.05$

As displayed in Table 4, greater body awareness and lesser time awareness correlated with satisfaction, desire and arousal. Body and time awareness were uncorrelated with orgasm. When sexual behaviours leading to orgasm were differentiated, a different pattern emerged (see Table 5): occurrence of coital orgasm without clitoral masturbation was associated with lesser time awareness. Additionally, there were nonsignificant trends towards greater body awareness being related to noncoital orgasm $(p=.081)$ and coital orgasm with clitoral masturbation $(p=.068)$.

Table 4. Pearson's correlation matrix between sexual function and changes in consciousness

\begin{tabular}{lccccccc}
\hline & 1 & 2 & 3 & 4 & 5 & 6 & 7 \\
\hline 1. Sexual satisfaction & - & & & & & \\
2. Desire & $.71^{* * *}$ & - & & & & \\
3. Arousal & $.71^{* * *}$ & $.87^{* * *}$ & - & & & \\
4. Orgasm & $.53^{* * *}$ & $.26^{* *}$ & $.29 * * *$ & - & & \\
5. Body awareness & $.53^{* * *}$ & $.47^{* * *}$ & $.42^{* * *}$ & .16 & - & \\
6. Space awareness & .004 & .04 & -.02 & -.13 & $.21^{* *}$ & - & \\
7. Time awareness & $-.19^{*}$ & $-.25^{* *}$ & $-.18^{*}$ & -.05 & $-.30^{* * *}$ & $.21^{* *}$ & - \\
\hline
\end{tabular}

Nota: *** $p \leq .001 ; * * p \leq .01 ; * p<.05$

Table 5. Pearson's correlations between orgasms and other sexual responses. 
SEXUAL FUNCTION, PERSONALITY, AND BODY AWARENESS

\begin{tabular}{cccc}
\hline & $\begin{array}{c}\text { Coital orgasm without } \\
\text { clitoral masturbation }\end{array}$ & $\begin{array}{c}\text { Coital orgasm with clitoral } \\
\text { masturbation }\end{array}$ & Noncoital Orgasm \\
\hline Body Awareness & .07 & $.16 \uparrow$ & $.15 \uparrow$ \\
Space Awareness & -.02 & .07 & -.11 \\
Time Awareness & $-.17^{*}$ & -.02 & -.03 \\
Sexual Satisfaction & $.28^{* * *}$ & $.22^{* *}$ & $.29^{* * *}$ \\
Arousal & $.21^{*}$ & .15 & $.26^{* *}$ \\
Desire & $.25^{* *}$ & $.17^{*}$ & $.16 \uparrow$ \\
\hline
\end{tabular}

For testing associations between orgasms during different sexual behaviours and personality, partial correlations controlling for body and time awareness were run. The significant associations were the following: occurrence of coital orgasm without clitoral masturbation was related to lower $\mathrm{N}$ $(r=-.25, p=.004)$, higher $\mathrm{E}(r=.18, p=.037)$, and higher $\mathrm{O}$ at trend level $(r=.16, p=.073)$; noncoital sex orgasm correlated with higher $\mathrm{E}(r=.18, p=.040)$.

Tables 6,7 , and 8 present multiple regressions predicting sexual responses in three blocks of predictors. In the last blocks, satisfaction was independently predicted by greater body awareness, being in a relationship, higher body awareness, higher $\mathrm{E}$, higher $\mathrm{O}$, and higher $\mathrm{C}$. Desire was independently predicted by greater body awareness, lower $\mathrm{N}$, and at trend level by higher $\mathrm{O}$. Arousal was independently predicted by greater body awareness, lower $\mathrm{N}$, and higher $\mathrm{O}$.

Table 6. Multiple regression predicting sexual satisfaction.

\begin{tabular}{cccc}
\hline Predictors & & & \\
\hline Model 1 & $\mathrm{B}$ & $p$ & $R^{2}$ \\
Age & .03 & .762 & .09 \\
Being in a relationship $^{1}$ & .30 & $>.001$ & $R^{2}$ \\
Model 2 & $\mathrm{B}$ & $p$ & .31 \\
Age & .08 & .281 & \\
Being in a relationship ${ }^{1}$ & .16 & .043 & $R^{2}$ \\
Body awareness & .47 & $>.001$ & .44 \\
Time awareness & -.05 & .559 & \\
Model 3 & $\mathrm{B}$ & $p$ & \\
Age & .01 & .840 & .007 \\
Being in a relationship & .20 & $>.001$ & \\
Body awareness & .45 & .824 & \\
Time awareness & -.02 & .014 & \\
Extraversion & .20 & .180 & .056 \\
Neuroticism & -.10 & .025 & .340 \\
Conscientiousness & .15 & .16 & .07 \\
Openness to experience & &
\end{tabular}

Nota: $* * * p \leq .001 ; * * p \leq .01 ; * p<.05 ; \uparrow p \leq .08$

${ }^{1}$ In a relationship $=1$; not in a relationship $=0$ 
Table 7. Multiple regression predicting sexual desire

\begin{tabular}{|c|c|c|c|}
\hline Predictors & & & \\
\hline Block 1 & $\beta$ & $p$ & $R^{2}$ \\
\hline Age & -.04 & .623 & .04 \\
\hline Being in a relationship ${ }^{1}$ & .20 & .024 & \\
\hline Block 2 & $\beta$ & $p$ & $R^{2}$ \\
\hline Age & .01 & .894 & .24 \\
\hline Being in a relationship ${ }^{1}$ & .06 & .455 & \\
\hline Body awareness & .41 & $>.001$ & \\
\hline Time awareness & -.13 & .118 & \\
\hline Block 3 & $\beta$ & $p$ & $R^{2}$ \\
\hline Age & -.04 & .572 & .30 \\
\hline Being in a relationship ${ }^{1}$ & .10 & .236 & \\
\hline Body awareness & .40 & $>.001$ & \\
\hline Time awareness & -.10 & .220 & \\
\hline Extraversion & .11 & .224 & \\
\hline Neuroticism & -.18 & .028 & \\
\hline Conscientiousness & .01 & .889 & \\
\hline Openness to experience & .14 & .075 & \\
\hline Agreeableness & .01 & .889 & \\
\hline
\end{tabular}

Nota: ${ }^{1}$ In a relationship $=1 ;$ not in a relationship $=0$

Table 8. Multiple regression predicting sexual arousal.

\begin{tabular}{cccc}
\hline Predictors & & & \\
\hline Block 1 & $\beta$ & $p$ & $R^{2}$ \\
Age & -.03 & .747 & .02 \\
Being in a relationship ${ }^{2}$ & .14 & .113 & $R^{2}$ \\
Block 2 & $\beta$ & $p$ & .18 \\
Age & .02 & .808 & \\
Being in a relationship ${ }^{1}$ & .01 & .897 & $R^{2}$ \\
Body awareness & .40 & $>.001$ & .28 \\
Time awareness & -.06 & .480 & \\
Block 3 & $\beta$ & $p$ & \\
Age & -.05 & .572 & .493 \\
Being in a relationship & .06 & $>.001$ & \\
Body awareness & .38 & .745 & \\
Time awareness & -.03 & .109 & \\
Extraversion & .15 & .009 & \\
Neuroticism & -.21 & .800 & .027 \\
Conscientiousness & -.02 & .800 & \\
Openness to experience & .18 & -.02 &
\end{tabular}

Nota: ${ }^{1}$ In a relationship $=1$; not in a relationship $=0$ 


\section{SEXUAL FUNCTION, PERSONALITY, AND BODY AWARENESS}

\section{DISCUSSION}

Consistently with literature, higher $\mathrm{E}$ and lower $\mathrm{N}$ correlated with higher desire, arousal and satisfaction during the last sexual intercourse. Additionally, $\mathrm{C}$ correlated with greater satisfaction. We also replicated previous findings by Costa et al. (2016) by showing that greater body awareness during intercourse correlated strongly with desire, arousal and satisfaction. As predicted, lesser time awareness during intercourse correlated with desire, arousal and satisfaction, but with moderate to weak effect sizes. In the study by Costa et al. (2016), these correlations were strong. One possibility for this discrepancy might have been the scale format. We used an 11-point scale from 0 to 10 , whereas Costa and colleagues used a visual analogue scale consisting of a $100 \mathrm{~mm}$ line on which respondents made a stroke (there were 101 possibilities of answer). There is research supporting that visual analogue scales are more exact and reliable when variables are continuous (Reips \& Funke, 2008). It is also possible that loss of time awareness is a less consistent alteration of consciousness. In the study by Costa et al. (2016), sexual responses correlated strongly with increased body awareness and decreased time awareness, but more strongly so with body awareness.

As shown in the regression models, time awareness is a not significant predictor after controlling for body awareness (see Tables 6, 7, and 8). We also replicated the finding of Costa et al. (2016) that, in women, greater body awareness correlates inversely with time awareness, indicating that greater attentional absorption in bodily sensations tends to occur concomitantly with loss of time awareness. The attentional absorption in pleasant bodily sensations may favour a loss of time awareness, and it is not mutually exclusive that greater predisposition to be focused on the present moment and the loss of the sense of time result from an increased attention to the body. This is actually what happens in other types of altered states of consciousness such as when experienced meditators manage to stay in the present moment and reduce their awareness of time through a trained focus on the body such as the breathing cycle or the body scan (Berkovich-Ohana et al., 2013; Droit-Volet \& Dambrun, 2019). We failed to find associations between greater sexual responses and loss of awareness of surrounding space. Costa et al. (2016) reported a correlation between lesser space awareness and female desire, but not arousal, satisfaction, and orgasm (and the correlation with space awareness was of moderate size). For women, decreased attention to surrounding space might not be a frequent alteration during moments of higher sexual responsiveness.

We found that body awareness was marginally greater for those who did have orgasm, but orgasm was unrelated to time awareness. This is not consistent with previous research where strong associations of female orgasm with greater body awareness and lesser time awareness were found. In addition to the fact that we did not used a visual analogue scale to measure time awareness, one likely reason is that most of the present sample ( $88 \%$ ) attained orgasm, which left reduced variance to detect statistically significant effects. But interestingly, when orgasm triggers were differentiated, orgasm during penile-vaginal intercourse with clitoral masturbation correlated with greater body awareness at trend level, and orgasm during penile-vaginal intercourse alone correlated with lesser time awareness. A similar pattern was observed in the study by Costa et al. (2016) who reported that greater body awareness correlated with occurrence of orgasm during penile-vaginal intercourse with clitoral masturbation, and perception of time passing quicker correlated with occurrence of orgasm during penile-vaginal intercourse without clitoral masturbation (Costa et al., 2016). Why orgasm during coitus alone would correlate with alterations in the perception of time but is not accompanied by intensification of body awareness presently remains an unanswered question. This may of course have to with methodological reasons such as employing a specific visual scale which is filled out in retrospect (days or weeks since the last intercourse).

As a parenthetical note, we found that occurrence of orgasm during coitus without clitoral masturbation correlated with lower $\mathrm{N}$ and higher $\mathrm{E}$, as well as with higher $\mathrm{O}$ at trend level. This pattern is similar to that reported by Harris and colleagues. In their study, occurrence of coital orgasm correlated with lower N, higher E, and higher O (Harris et al., 2008). Coital orgasm without the direct 
stimulation of the clitoris (often named vaginal orgasm) and is a matter of controversy. Unlike previously thought, recent studies show physiological differences between vaginal and clitoral orgasm (Brody, 2017; Jannini et al., 2019; Jannini et al., 2012). Many women report to not attain vaginal orgasm at all or on a regular basis, which makes it an intriguing subject. Several studies on correlates of vaginal orgasm suggest that its occurrence is contingent on a variety of factors, and that makes its occurrence more unlikely. The findings of the present study and the extant literature suggest that it might be facilitated by the anatomical characteristics of the urethrovaginal space (Battaglia et al., 2010; Gravina et al., 2008), genetic influences (Dawood et al., 2005), male sexual function (Brody \& Weiss, 2010; Weiss \& Brody, 2011), round back-and-forth pelvic movements (Bischof-Campbell et al., 2019), deeper changes in consciousness (Costa et al., 2016; Ellero \& Costa, 2020), hypnotic susceptibility (a possible facilitator of deeper changes in consciousness) (Bridges et al., 1985), better mood (as indicated by lower N, higher E, and other indicators of better mood; Costa \& Brody, 2012; Harris et al., 2008; Weiss \& Brody, 2011), and higher O (that is, openness to emotional, esthetical, and intellectual experiences) (Harris et al., 2008). The mechanisms involved are not clear, and several other factors have been discussed (Brody \& Weiss, 2010).

In multiple regressions, body awareness appears as the strongest predictor of sexual responses, but personality traits explain additional variance. Satisfaction was independently predicted by greater body awareness and higher E, O, and C. Desire was independently predicted by greater body awareness and lower N. Additionally, there was a nonsignificant trend for greater $\mathrm{O}$ being related to desire. Sexual arousal was independently predicted by greater body awareness, lower $\mathrm{N}$ and higher $\mathrm{O}$. It is interesting to note that $\mathrm{O}$ was unrelated to satisfaction and arousal in univariate analyses. It is important for future research to pay attention to those traits that have a more inconsistent relation to sexuality $(\mathrm{O}$ and $\mathrm{A})$ as it is possible that these traits are more consistently related to better sexual functioning after other variables having been controlled.

The importance of awareness of body in sexual functioning is well documented (Berenguer et al., 2019; Costa et al., 2016). The reason why $\mathrm{N}$ interferes with sexual functioning is likely because it increases the likelihood of dysphoric mood. In contrast, $\mathrm{E}$ is likely related to better sexual functioning because it increases the likelihood of positive mood. The reason why $\mathrm{C}$ is associated with better sexual function is more difficult to explain. One possibility is that people high in C look more trustful to their partners, and this fosters comfort in sexual interactions. People higher in $\mathrm{C}$ are less likely to use alcohol or other drugs that interfere with sexual function, but that does not explain the present results, as we restricted the analyses to those women who were not under the effect of psychoactive substances (with the exception of nicotine). The associations between $\mathrm{O}$ and sexual function are also difficult to explain. It is possible that people more open to experience are more creative in sexual interactions. In addition, $O$ has been related to attentional absorption (Costa et al., 2016; 2018), and greater disposition to experience absorbed states might lead to higher sexual responsiveness, as absorption may increase fascination by partners and sensory engrossment in sexual activity (Costa et al., 2016; 2018).

It is worth noting that being in a relationship was associated with greater desire and satisfaction, as well as with greater body awareness during sexual activity. In the regression models, we can see that the effect sizes of the correlations between relationship status and sexual responses are greatly reduced after controlling for body awareness. It is worth noting that being in a relationship was associated with satisfaction, to a lesser extent with desire, and was unrelated to arousal. It appears that the fact of being in a relationship can provide a comfort that promotes sexual satisfaction.

Ellero and Costa (2020) queried men and women about sexual responsiveness during the last sexual relation, as well as about cognitive and emotional changes that occurred during or shortly after. For both sexes, desire, arousal, and satisfaction, correlated with states of bliss, sudden insights, and reduction of psychological differentiation between self and external world (sense of unity). These correlations remained after controlling for trait absorption, that is, a personality trait that reflects individual differences in propensity to experience deeper altered states of consciousness by a variety www.sp-ps.pt 


\section{SEXUAL FUNCTION, PERSONALITY, AND BODY AWARENESS}

of triggers (Lifschitz et al., 2019). This suggests that sexual responses can be high enough to trigger a variety of changes of consciousness regardless of individual proclivities based on personality.

In sum, sexual responsiveness appears to be independently influenced by relatively stable factors (personality traits) and more transient ones (attention to bodily sensations and loss of time awareness).

\section{REFERENCES}

Allen, M. S., \& Walter, E. E. (2018a). Linking big five personality traits to sexuality and sexual health: A meta-analytic review. Psychological Bulletin, 144(10), 1081-1110. https://doi.org/10.1037/bul0000157.

Allen, M. S., \& Walter, E. E. (2018b). Health-related life style factors and sexual dysfunction: a metaanalysis of population-based research. Journal of Sexual Medicine, 15(4), 458-475. https://doi.org/10.1016/j.jsxm.2018.02.008

Battaglia, C., Nappi, R. E., Mancini, F., Alvisi, F., Del Forno, S., Battaglia, B., \& Venturoli, S. (2010). 3-D volumetric and vascular analysis of the urethrovaginal space in young women with and without vaginal orgasm. Journal of Sexual Medicine, 7(4), 1445-1453. https://doi.org/10.1111/j.1743-6109.2009.01650.x

Berenguer, C., Rebolo, C., \& Costa, R. M. (2019). Alexithymia, interoceptive awareness, and sexual function. Journal of Sex \& Marital Therapy, 45(8), 729-738. https://doi.org/10.1080/0092623X.2019.1610128

Berkovich-Ohana, A., Dor-Ziderman, Y., Glicksohn, J., \& Goldstein, A. (2013). Alterations in the sense of time, space, and body in the mindfulness-trained brain: a neurophenomenologicallyguided MEG study. Frontiers in Psychology, 4(912). https://doi.org/10.3389/fpsyg.2013.00912

Bertoquini, V., \& Pais Ribeiro, J. L. (2006). Estudo de formas muito reduzidas do Modelo dos Cinco Factores da Personalidade. Psychologica, 43, 193-210.

Bischof-Cambpell, A., Hilpert, P., Burri, A., \& Bischof, K. (2019). Body movement is associated with orgasm during vaginal intercourse in women. Journal of Sex Research, 56(3), 356-366. https://doi.org/10.1080/00224499.2018.1531367

Bridges, C. F., Critelli, J. W., \& Loos, V. E. (1985). Hypnotic susceptibility, inhibitory control, and orgasmic consistency. Archives of Sexual Behavior, 14, 373-376. https://doi.org/10.1007/BF01550852

Brody, S. (2017). Evaluation of female orgasmic disorder. In W. IsHak (Ed.) Textbook of Clinical Sexual Medicine (pp. 203-218). Springer, Cham.

Brody, S., \& Weiss, P. (2010). Vaginal orgasm is associated with vaginal (not clitoral) sex education, focusing mental attention on vaginal sensations, intercourse duration, and a preference for a longer penis. Journal of Sexual Medicine, 7(8), 2774-2781. https://doi.org/10.1111/j.17436109.2009.01469.x

Cardoso, C., \& Costa, R. (2020). Funcionamento sexual e consumo de tabaco numa amostra jovem Psicologia, Saúde \& Doenças, 21(2), 22-273. https://doi.org/10.15309/20psd210203

Costa, R. M., \& Brody, S. (2012). Greater resting heart rate variability is associated with orgasms through penile-vaginal intercourse, but not with orgasms from other sources. Journal of Sexual Medicine, 9(1), 188-197. https://doi.org/10.1111/j.1743-6109.2011.02541.x

Costa, P. T., Fagan, P. J., Piedmont, R. L., Ponticas, Y., \& Wise, T. N. (1992). The five-factor model of personality and sexual functioning in outpatient men and women. Psychiatric Medicine, 10(2), 199-215. 
Costa, P. T., Jr., \& McCrae, R. R. (1992). Revised NEO Personality Inventory (NEO-PI-R) and NEO Five-Factor Inventory (NEO-FFI) professional manual. Psychological Assessment Resources.

Costa, R. M., Pestana, J., \& Costa, D. (2018) Self-transcendence, sexual desire, and sexual frequency. Journal of Sex \& Marital Therapy, 44(0), 56-60. https://doi.org/10.1080/0092623X.2017.1314397

Costa, R. M., Oliveira, T. F., Pestana, J., \& Costa, D. (2016). Self-transcendence is related to higher female sexual desire. Personality and Individual Differences, 96, 191-197.

Costa, R. M., Pestana, J., Costa, D., \& Wittmann, M. (2016). Altered states of Consciousness are related to higher sexual responsiveness. Consciousness and Cognition, 42, 135-141. https://doi.org/10.1016/j.concog.2016.03.013

Dawood, K., Kirk, K. M., Bailey, J. M., Andrews, P. W., \& Martin, N. G. (2005). Genetic and environmental influences on the frequency of orgasm in women. Twin Research and Human Genetics, 8(1), 27-33. https://doi.org/10.1375/1832427053435427

Droit-Volet, S., \& Dambrun, M. (2019). Awareness of the passage of time and self-consciousness: What do meditators report? PsyCh Journal, 8(1), 51-65.

Ellero, J., \& Costa, R. (2020). Altered states of consciousness, absoption, and sexual responsiveness. Psicologia, Saúde \& Doenças, 21(3), 782-795. https://doi.org/10.15309/20psd210320

Eysenck, H. J. (1971). Personality and sexual adjustment. British Journal of Psychiatry, 118(547), 593-608. https://doi.org/10.1192/bjp.118.547.593

Gravina, G. L., Brandetti, F., Martini, P., Carosa, E., Di Stasi, S. M., Morano, S., Lenzi, A., \& Jannini, E. A. (2008). Measurement of the thickness of the urethrovaginal space in women with or without vaginal orgasm. The Journal of Sexual Medicine, 5(3), 610-618. https://doi.org/10.1111/j.17436109.2007.00739.x

Harris, J. M., Cherkas, L. F., Kato, B. S., Heiman, J. R., \& Spector, T. D. (2008). Normal variations in personality are associated with coital orgasm infrequency in heterosexual women: a populationbased study. Journal of Sexual Medicine, 5(5), 1177-11883. https://doi.org/10.1111/j.17436109.2008.00800.x

Jannini, E., Rubio-Casillas, A., Whipple, B., Buisson, O., Komisaruk, B., \& Brody, S. (2012). Female orgasm(s): one, two, several. Journal of Sexual Medicine, 9(4), 956-965. https://doi.org/10.1111/j.1743-6109.2012.02694.x

Jannini, E., Wise, N., Frangos, E., \& Komisaruk, B. R. (2019). Peripheral and central neural bases of orgasm. In I. Goldstein, A. H., Clayton, A. T. Goldstein, N. N. Kim, S. A. Kingsberg (Eds), Textbook of Female Sexual Function and Dysfunction (pp. 179-185). Wiley-Blackwell. https://doi.org/10.1002/9781119266136.ch13

Jirjahn, U., \& Ottenbacher, M. (2020). Big five personality traits and sex. IZA - Institute of Labor Economics. https://www.iza.org/publications/dp/13894/big-five-personality-traits-and-sex

Kurpisz, J., Mak, M., Lew-Starowicz, M., Nowosielski, K., Bieńkowski, P., Kowalczyk, R., Misiak, B., Frydecka, D., \& Samochowiec, J. (2016). Personality traits, gender roles and sexual behaviours of young adult males. Annals of general psychiatry, 15, 28. https://doi.org/10.1186/s12991-0160114-2

Lifschitz, M., van Elk, M., \& Luhrmann, M. (2019). Absorption and spiritual experience: A review of evidence and potential mechanisms. Consciousness and Cognition, 73, 102760. https://doi.org/10.1016/j.concog.2019.05.008

Meltzer, A. L., \& McNulty, J. K. (2016). Who is having more and better sex? The big five as predictors of sex in marriage. Journal of Research in Personality, 63, 62-66. https://doi.org/10.1016/j.jrp.2016.05.010 
McCrae, R. R., \& Costa, P. T., Jr. (1997). Personality trait structure as a human universal. American Psychologist, 52(5), 509-516. https://doi.org/10.1037/0003-066X.52.5.509

Quinta Gomes, A. L., \& Nobre, P. (2011). Personality traits and psychopathology on male sexual dysfunction: An empirical study. Journal of Sexual Medicine, 8(2), 461-469. https://doi.org/10.1111/j.1743-6109.2010.02092.x

Reips, U. D., \& Funke, F. (2008). Interval-level measurement with visual analogue scales in Internetbased research. Behavior Research Methods, 40(3), 699-704. https://doi.org/10.3758/BRM.40.3.699

Velten, J., Brailovskaia, J., \& Margraf, J. (2018). Exploring the impact of personal and partner traits on sexuality: sexual excitation, sexual Inhibition, and Big Five predict sexual function in couples. Journal of sex research, 56(3), 287-299. https://doi.org/10.1080/00224499.2018.1491521

Weiss, P., \& Brody, S. (2011). International Index of Erectile Function (IIEF) scores generated by men or female partners correlated equally well with own satisfaction (sexual, partnership, life, and mental health). Journal of Sexual Medicine, 8(5), 1404-1410. https://doi.org/10.1111/j.17436109.2011.02214.x

Wittmann, M. (2015). Modulations of the experience of self and time. Consciousness and Cognition, 15(38), 172-181. https://doi.org/10.1016/j.concog.2015.06.008 